\title{
Pengaruh Pembiayaan Mudharabah dan Musyarakah Terhadap Return On Asset BPRS di Indonesia
}

\author{
Faris Kurnia Hakim dan Mauizhotul Hasanah \\ Program Studi Magister Sains Ekonomi Islam, Fakultas Ekonomi dan Bisnis, \\ Universitas Airlangga \\ Email:fariskhakim@gmail.com,hasanahidzoh@gmail.com
}

\begin{abstract}
Abstrak: Sebagai lembaga perantara BPRS memiliki fasilitas pada bidang pembiayaan dimana bank syariah menyalurkan dana yang diperoleh dari masyarakat dalam bentuk simpanan. Penelitian ini dilakukan untuk mengetahui pengaruh pembiayaan mudharabah dan musyarakah secara simultan dan parsial terhadap Return On Asset Bank Pembiayaan Rakyat Syariah di Indonesia. Objek penelitian adalah seluruh Bank Pembiayaan Rakyat Syariah di Indonesia mulai Januari 2016 sampai dengan Desember 2018. Pendekatan penelitian yang digunakan adalah pendekatan kuantitatif. Teknik analisis yang digunakan adalah regresi linear berganda atau OLS (Ordinary Least Squares). Hasil penelitian ini adalah pembiayaan dengan menggunakan akad mudharabah dan musyarakah secara simultan tidak berpengaruh signifikan ke arah positif terhadap Return On Asset Bank Pembiayaan Rakyat Syariah di Indonesia. Pembiayaan mudharabah secara parsial tidak berpengaruh signifikan ke arah positif terhadap Return On Asset Bank Pembiayaan Rakyat Syariah di Indonesia. Pembiayaan musyarakah secara parsial tidak berpengaruh signifikan ke arah negatif terhadap Return On Asset Bank Pembiayaan Rakyat Syariah di Indonesia.
\end{abstract}

Kata kunci: Mudharabah, Musyarakah, Return On Asset (ROA).

Abstract: As an intermediary institution, BPRS has facilities in the field of financing where Islamic banks channel funds obtained from the public in the form of deposits. This research was conducted to determine the effect of mudharabah and musyarakah financing simultaneously and partially on the Return On Assets of Islamic People's Financing Banks in Indonesia. The object of research is all Islamic People's Financing Banks in Indonesia from January 2016 to December 2018. The research approach used is a quantitative approach. The analysis technique used is multiple linear regression or OLS (Ordinary Least Squares). The results of this study are the financing using mudharabah and musyarakah contracts simultaneously does not have a significant positive effect on the Return on Assets of Islamic People's Financing Banks in Indonesia. Mudharabah financing partially does not have a significant positive effect on the Return on Assets of the Islamic People's Financing Bank in Indonesia. Musyarakah financing partially does not have a significant negative effect on the Return On Assets of the Islamic People's Financing Bank in Indonesia.

Keywords: Mudharabah, Musyarakah, Return On Asset (ROA). 


\section{PENDAHULUAN}

Perekonomian modern tidak dapat bergerak tanpa kehadiran industri perbankan, karena perbankan disebut sebagai industri yang menunjang perputaran roda perekonomian suatu negara yang memiliki peran sangat vital demi mencapai tujuan suatu negara yaitu untuk peningkatan kesejahteraan hidup masyarakat. Sebagai alat financial intermediacy industri perbankan memiliki dua fungsi yang wajib dijalankan yaitu mempertemukan antara pihak yang memiliki kelebihan dana disebut fungsi penghimpun dana dengan pihak yang membutuhkan dana disebut fungsi penyaluran dana. Bank syariah atau BPRS sebagai lembaga perantara berfokus pada penyaluran dana yang melayani seluruh lapisan masyarakat terutama pada pengusaha menengah, kecil, dan mikro (Sudrajat, 2015) yang bertujuan untuk memperkuat perekonomian nasional karena di Indonesia pengusaha lebih didominasi oleh UMKM.

Berdasarkan fungsi penyaluran dana BPRS memiliki fasilitas sebagai sarana pembiayaan dimana bank syariah menyalurkan dana yang didapat dari masyarakat dalam bentuk simpanan. Ketika bank syariah memberikan pembiayaan kepada nasabah yang telah disetujui bersama hal ini akan mempengaruhi tingkat profitabilitas bank syariah sehingga jika pembiayaan tersebut berjalan lancar maka akan berdampak pada profitabilitas bank syariah yang bagus namun tidak semua pembiyaan berjalan lancar ada kalanya pembiayaan mengalami kemacetan atau gagal bayar sehingga akan berdampak buruk pada profitabilitas bank syariah. Sehingga bank syariah harus lebih teliti ketika menyalurkan pembiyaaan agar tepat sasaran. Menurut (Rokhmah dan Komariah, 2017) rasio profitabilitas dapat diukur dengan dua pendekatan yaitu dalam bentuk penjualan dan investasi, ukuran yang digunakan salah satunya Return on Assets (ROA) dan Return on Equity (ROE) yang menjadi daya tarik dalam bisnis. Perbedaan tingkat profitabilitas (ROA) bank syariah diperngaruhi oleh banyak fakor, jenis aktor yang dapat mempengaruhi tingkat perubahan keuntungan suatu bank yaitu dapat berasal dari faktor internal dan eksternal bank syariah (Rosiana et al., 2019)

Pebankan di Indonesia terbagi menjadi dua bank yaitu bank syariah dan bank konvensional. Keduanya memiliki produk yang hampir sama, namun perbedaannya pada sistem operasionalnya, bank konvensional menggunakan sistem bunga sedangkan bank syariah menggunakan sistem bagi hasil. Produk dari bank syariah yang menggunakan bagi hasil berupa pembiayaan modal kerja dan investasi dalam bentuk pembiayaan mudharabh dan musyarakah (Permata dkk., 2014). Menurut (Muhammad, 2005a), pembiayaan mudharabah dan musyarakah mempengaruhi kinerja keuangan lembaga keuangan syariah yang ditampilkan di rasio yaitu ROA. Pembiayaan mudharabah dan musyarakah di bankbank pembiayaan rakyat syariah yang meningkat dari tahun ke tahun. Peningkatan tersebut juga ditunjukkan oleh Return On Asset bank pembiayaan rakyat syariah. Namun, pembiayaan dengan tidak menggunakan pembiayaan mudharabah dan musyarakah (murabahah) di bank pembiayaan rakyat syariah masih mendominasi pembiayaan. Adapun perkembangan Return on Asset BPRS di Indonesia pada periode 2012 hingga 2018 sebagai berikut: 
Gambar 1. Perkembangan Return on Asset BPRS di Indonesia Periode 2012-2018

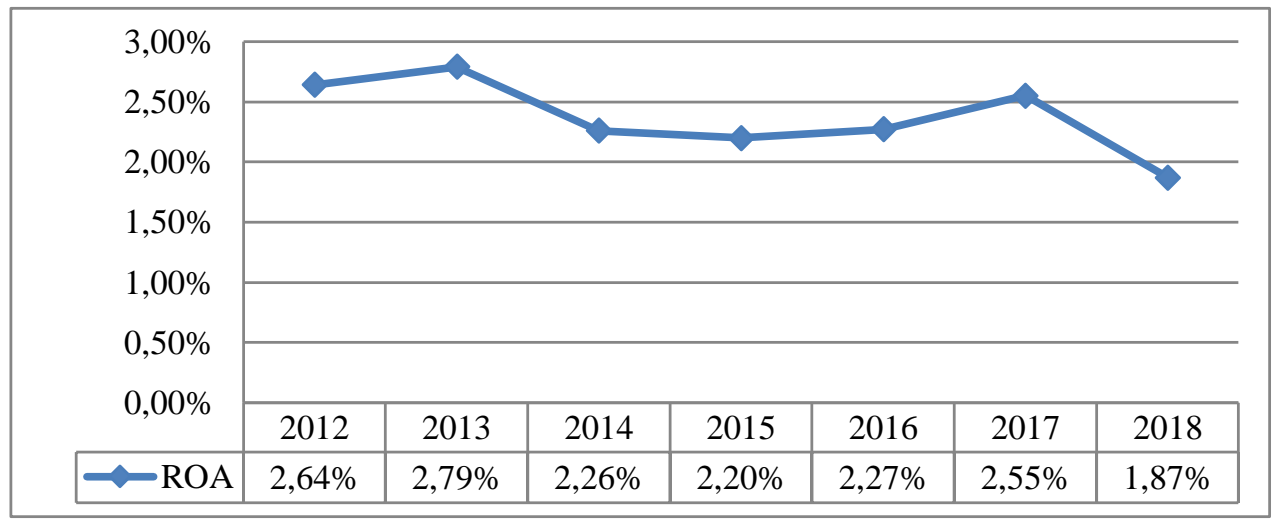

Sumber: (OJK, 2015-2019)

Berdasarkan gambar diatas ROA di tahun 2014 mengalami penurunan dibanding tahun sebelumnya sebesar 0,06\% kemudian di tahun 2017 mengalami kenaikan sebesar 0,28\% dai tahun sebelumnya dan ditahun 2018 mengalami penurunan kembali hingga mencapai $0,68 \%$. Penurunan di tahun 2018 tersebut merupakan penurunan paling dalam dibandingkan tahun sebelumnya. Menurut (Dewi, 2019) pembiayaan di bank syariah dibedakan berdasarkan jenisnya, yaitu (1) pembiayaan dengan prinsip bagi hasil, menggunakan akad mudharabah dan muyarakah. (2) pembiayaan dengan prinsip jual beli, menggunakan akad murabahah, salam, dan istishna. (3) pembiayaan menggunakan pinsip sewa, menggunakan akad ijarah dan ijarah muntahiyah bitamlik (IMBT). Disamping itu, pembiyaan di BPRS ada yang ditujukan pada sektor produktif dan termasuk dalam aset yang menghasilkan pendapatan (aktiva produktif). Aktiva produktif bisa berupa pembiayaan mudharabah dan musyarakah.

BPRS merupakan salah satu dari sektor keuangan Islam, prinsip utama dari bank Islam adalah kesejahteraan masyarakat yang mengarah pada kondisi soasial yang damai. Sehingga produk yang ditawarkan oleh bank syariah mengacu pada nilai-nilai Islam yang adil dan tanpa bunga. Adapun perbedaan yang sangat signiikan antara bank konvnsional dan bank syariah yaitu produk pinjaman terdapat pada bank konvensional dan keuangan pada bank syariah. Pembiayaan pinjaman berbeda artinya nasabah dalam meminjam uang dari bank yang bertujuan untuk kebutuhannya dengan dikenakan bunga tertentu, sedangkan pembiaayaan bank artinya untuk membiayai seluruh kebutuhan nasabah dengan perjanjian yang disepakati berdasarkan kontrak bagi hasil dan kontrak pembelian berdasrkan sewa (Yuliana et al., 2017)

Berdasarkan penelitian terdahulu, menurut (Ogilo, 2016) menyimpulkan bahwa musyarakah, ijarah, dan murabahah memiliki pengaruh positif terhadap ROA. Maka ketika pembiayaan musyarakah mengalami peningkatan maka akan meningkatkan kinerja dari bank syariah pula, hal ini maka bank syariah di Indonesia untuk lebih meningkatkan pembiayaan musyarakah agar dapat memaksimalkan pengembalian aset bank syariah. Menurut (Jaurino dan Renny, 2017) menyimpulkan dari hasil penelitiannya yaitu pembiayaan mudharabah memiliki pengaruh positif dan signifikan terhadap profitabilitas bank. Namun pembiayaan musyarakah tidak berpengaruh terhadap profitabilitas bank. (Rokhmah dan Komariah, 2017) pembiayan mudharabah dan musyarakah secara simultan 
berpengaruh positif terhadap profitabilitas (ROA) Bank Syariah. Menurut (Nawawi dkk., 2018) Pembiayaan mudharabah dan pembiayaan musyarakah berpengaruh signifikan pada profitabilitas berupa Return on Assets (ROA) BPRS HIK Bekasi Kantor Cabang Karawang periode 2009-2016. Menurut (Agza dan Darwanto, 2017) pembiayaan Murabahah, Musyarakah dan Biaya Transaksi memiliki pengaruh signifikan terhadap profitabilitas (ROA) Bank Pembiayaan Rakyat Syariah. Menurut (Irmawati, 2018) menyimpulkan bahwa musyarakah berpengaruh secara positif terhadap profitabilitas di PT BPRS Lantabur Tebuireng, sedangkan variabel mudharabah berpengaruh signifikan secara negatif terhadap profitabilitas.

Menurut (Muhammad, 2005b), ketika pendapatan lembaga keuangan syariah yang berasal dari pembiayaan mudharabah dan musyarakah meningkat dan biaya yang ditimbulkan oleh pembiayaan tersebut telah menurun atau tetap, ROA lembaga keuangan syariah meningkat. Kemudian, jika pendapatan lembaga keuangan syariah berasal dari pembiayaan mudharabah dan musyarakah menurun dan biaya yang ditimbulkan oleh pembiayaan mudharabah dan musyarakah meningkat atau tetap, maka ROA lembaga keuangan syariah menurun. Dari penjelasan di atas, dapat dikatakan bahwa pembiayaan mudharabah dan musyarakah berpengaruh terhadap ROA (Return On Asset) bank pembiayaan rakyat syariah. Namun berbeda dengan hasil penelitian dari menurut (Dharma dan Pristianda, 2018) mudharabah tidak berpengaruh terhadap profitabilitas (ROA) BPRS di Indonesia pada tahun 2012 hingga 2016. Penelitian ini bertujuan untuk mengetahui seberapa besar pengaruh pembiayaan mudharabah dan musyarakah terhadap Return On Asset (ROA) Bank Pembiayaan Rakyat Syariah di Indonesia. Selanjutnya penelitian dari (Fatmawati, 2016) yang menyimpulkan bahwa variabel mudharabah secara parsial tidak bepengaruh secara positif dan variabel musyarakah tidak berpengaruh secara negatif.

Setiap perbankan pasti menghimpun dana dan mengalokasikan dananya pada kegiatan yang akan menghasilkan keuntungan, keuntungan tersebut akan dibagikan antara kedua pihak sehingga hasil keuntungan tersebut akan digunakan untuk pengembalian modal , kemudian dari pengembalian modal tersebutlah dapat mengukur tingkat profitabilitas bank dengan cara menggunakan rasio ROA. Oleh karena itu, penelitian ini bertujuan untuk menganalisis pengaruh pembiayaan berupa akad mudharabah dan musyarakah yang berpengaruh pada Return on Asset (ROA) Bank Pembiayaan Rakyat Syariah di Indonesia.

\section{KAJIAN TEORI}

Bank Syariah. Menurut (Muhamad, 2005c), bank syariah adalah bank yang beroperasi dengan tidak mengandalkan pada bunga yaitu suatu lembaga keuangan yang usaha pokoknya memberikan pembiayaan dan jasa-jasa lainnya dalam lalu lintas pembayaran serta peredaran uang yang dioperasikan berdasarkan dengan prinsip Islam. Menurut UU Nomor 21 Tahun 2008, Bank Syariah adalah bank yang menjalankan kegiatan usahaanya berdasarkan prinsip-prinsip syariah dan menurut jenisnya terdiri dari Bank Umum Syariah (BUS) dan Bank Pembiayaan Rakyat Syariah (BPRS) (Rustam, 2013). Menurut (Rivai et al., 2007), bank syariah memiliki dua peran yang dijalankan oleh bank syariah yaitu bank syariah berperan sebagai badan usaha (tamwil), dan bank syariah berperan sebagai badan sosial ( $\mathrm{mal})$. 
Tujuan utama sistem perbankan dan keuangan Islam berdasarkan perspektif Islam sebagai berikut: (1) penghapusan bunga dari semua transaksi keuangan dan pembaruan semua aktivitas bank agar sesuai dengan prinsip Islam. (2) distribusi pendapatan dan kekayaan yang wajar, dan (3) mencapai kemajuan pembangunan ekonomi (Nafik dan Wahyudi, 2018). Lalu, tujuan dari bank syariah menurut (Rivai et al., 2012) sebagai berikut: (1) menunjang pelaksanaan pembangunan nasional dalam rangka meningkatkan keadilan, kebersamaan, dan pemerataan kesejahteraan rakyat. (2) menawarkan jasa keuangan yang sesuai dengan prinsip Islam dan berfokus pada pembiayaan yang berdasarkan pembagian risiko dan aktivitas yang halal. (3) menstabilkan nilai uang dengan sistem tanpa bunga. (4) mengembangkan ekonomi melalui pembiayaan yang disalurkan kapada pengusaha baik dengan akad mudharabah maupun akad musyarakah. (5) mengoptimalkan sumber daya melalui pembiayaan yang disalurkan oleh bank syariah melalui proyek-proyek yang dapat menghasilkan keuntungan yang tinggi dan sesuai dengan prinsip-prinsip Islam

Return On Asset (ROA). Gambaran dari pencapaian keberhasilan suatu perusahaan atas berbagai aktivitas yang telah dilakukan terdapat pada kinerja keuangan. Profitabilitas salah satu ukuran dalam kinerja keuangan yang diartikan sebagai tingkat kemampuan perusahaan dalam menghasilkan laba dimana profitabilitas merupakan laba sebelum pajak dengan total aset yag dimiliki pada bank pada periode tertentu (Fadihila, 2015). Profitabilitas merupakan indikator yang paling tepat untuk mengukur kinerja suatu bank. Ukuran profitabilitas yang dapat digunakan yaitu Return On Asset (ROE) untuk perusahaan pada umumnya dan Return On Asset (ROA) pada industri perbankan (Syofyan, 2003). ROA memperlihatkan bahwa kemampuan perusahaan dalam menggunakan semua aset yang dimiliki untuk menghasilkan keuntungan. Rasio ini penting untuk manajemen demi mengevaluasi efektifitas dan efisiensi manajemen perusahaan dalam penggunaan seluruh aset perusahaan (Sudana, 2009). Tingkat net keuntungan (laba) diperoleh oleh lembaga keuangan syariah dipengaruhi oleh beberapa faktor, termasuk pendapatan dan pengeluaran. Aset yang menghasilkan pendapatan adalah pembiayaan dengan menggunakan akad mudharabah dan musyarakah (Arifin, 2003).

Adapun rasio Return on Asset (ROA) ini dapat dirumuskan sebagai berikut:

$$
R O A=\frac{\text { Laba Bersih }}{\text { Total Aktiva }} \times 100 \%
$$

Semakin besar nilai ROA, maka semakin besar pula kinerja BPRS, karena keuntungan yang diperoleh BPRS semakin besar (Rahmani, 2019). Ketika semakin besar ROA BPRS maka semakin efisien dan efektif penggunaan aset oleh BPRS atau dengan jumlah aset yang sama dapat menghasilkan keuntungan yang lebih besar.

Mudharabah. Mudharabah merupakan salah satu dari pembiayaan yang berprinsip bagi hasil yaitu perkongsian (kerja sama) usaha antara dua pihak atau lebih dimana salah satu pihak (Shohibul maal) mendanai 100\% dan pihak yang lain (mudharib) mengelola dana berdasarkan keahliannya, dan hasilnya akan dibagi berdasarkan nisbah yang disepakati di awal (Nafik, 2018). Selain itu, mudharabah ialah kontrak kerjasama antara dua pihak, di 
mana pihak pertama (shahibul maal) menyertakan seluruh modal (100\%) sementara pihak kedua menjadi manajer bisnis (mudharib) (Antonio, 2001).

Secara umum, berdasarkan jumhul ulama' rukun dan syarat mudharabah terdiri dari: (1) Ijab dan qabul: harus jelas, harus bertemu, dan harus sesuai yang dimaksudkan antara kedua belah pihak, (2) kedua pihak yang melakukan kerjasama (al-'Aqidain): cakap bertindak hukum secara syar'i, memiliki kewenangan mewakilkan atau membei kuasa dan menerima pemberian kuasa, dan pemilik modal, (3) Adanya modal: modalnya harus jelas jumlah dan jenisnya, harus berupa uang, uang tunai, modal diserahkan langsung, dan modal harusnya ditentukan hak nya. (4) Adanya pekerjaan atau usaha ( $A l$-' $a m l)$, (5) Nisbah keuntungan: Keuntungan dalam perjanjian harus jelas, keuntungan dikhususkan kepada kedua belah pihak (Sa'diyah dan Arifin 2013). Pembiayaan mudharabah pada perbankan syariah di Indonesia secara teknis beupa pembiayaan yang ditujukan untuk membiayai investasi, modal keja, dan penyediaan fasilitas. Perhitungan hasil menggunakan metode revenue sharing karena risiko yang ditanggung lebih kecil kerugiannya. Pendapatan pada mudharib tergantung pada ketidakpastian usaha dan biaya yang ditimbulkan pada proses usaha tersebut (Ascarya, 2011).

Adapun landasan dalam Al-Quran mengenai mudharabah yang mencerminkan anjuran untuk melakukan usaha dalam surat Al-Muzzammil ayat 20 sebagai berikut:

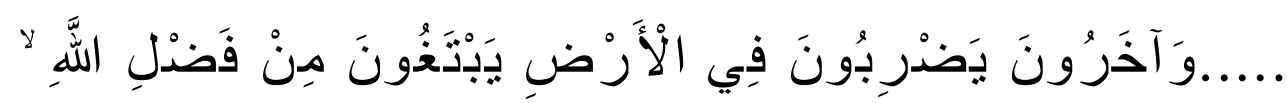

“....dan dari orang-orang yang berjalán di muka bumi mencari sebagian karunia Allah SWT...."

Berdasarkan ayat diatas bahwa terdapat kata yadhribun yang sama dengan akar kata mudharabah artinya melakukan suatu perjalanan usaha (Antonio, 2001).

Musyarakah. Musyarakah merupakan suatu akad antara dua orang atau lebih untuk berkongsi modal dan bersekutu dalam hasil usaha, kemudian keuntungan dibagi sesuai dengan kesepakatan sedangkan kerugian ditanggung berdasarkan porsi modal (Nafik dan Wahyudi, 2018). Pembiayaan musyarakah adalah pembiayaan yang menggunakan kontrak kerjasama bisnis antara dua pihak atau lebih untuk bisnis tertentu. Setiap pihak memberikan sumbangan dana. Bisnis keuntungan dan kerugian yang akan ditanggung sepanjang sesuai dengan kesepakatan (Antonio, 2001). Berdasarkan Jumhur 'ulama bahwa akad merupakan hal terpenting yang harus dilakukan dalam syarikah.

Adapun rukun syikah menurut para ulama sebagai berikut: (1) Sighat (Ijab dan Qabul), (2) Al-'Aqidain: orang yang berakal, baligh, merdeka atau tidak dalam paksaan, (3) Mahallul Aqd (Objek perikatan): modal yang diberikan harus tunai dan nilainya sama, (2) modal yang didapat dari aset perdagangan, modal yang disertakan oleh masing-masing pihak dijadikan satu (Sa'diyah dan Aziroh, 2014). Secara teknis pembiayaan musyarakah pada perbankan syariah di Indonesia yaitu sama dengan pembiayaan mudharabah, berupa menggunakan metode revenue sharing karena risikonya rendah. Jika menggunakan pembiayaan musyarakah pemiliki dana tidak pernah rugi atau minimal bagi hasil $=0$ (Ascarya, 2011).

Adapun landasan dalam Al-Quran mengenai musyarakah dalam surat Shaad ayat 24 sebagai berikut: 


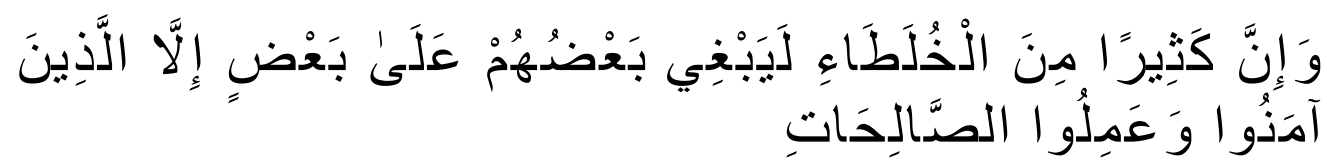

"Dan sesungguhnya kebanyakn dari orang-orang yang berserikat itu sebagian mereka berbuat zalim kepada sebagian yang lain kecuali orang yang beriman dan mengerjakan amal shaleh"

Berdasarkan ayat diatas menunjukan pengakuan Allah SWT akan adanya perserikatan dalam kepemilikan harta (Antonio, 2001).

\section{METODELOGI}

Penelitian ini menggunakan pendekatan kuantitatif eksplanatori, dengan metode analisis regresi berganda dengan menggunakan alat Eviews 9 yang bertujuan untuk menjelaskan pengaruh antara satu variabel dengan variabel yang lainnya. Adapun variabel dalam penelitian ini yaitu Return On Asset (ROA) (Y), Pembiayaan Mudharabah (X1), Pembiayaan Musyarakah (X2). Data yang digunakan berupa data sekunder berupa data time series (data runtut waktu), untuk motode pengambilan sampel menggunakan non probability sampling (sampling jenuh) meupakan teknik penentuan sampe jika semua anggota populasi digunakan sebagai sampel. Sampel data dalam bentuk bulanan mencakup periode Januari 2016 hingga Desember 2018. Data tersebut diperoleh dari statistik perbankan syariah yang diterbitkan oleh Otoritas Jasa Keuangan Adapun model hipotesisnya sebagai berikut.

Gambar diatas adalah model analisis yang membahas pengaruh variabel bebas yang terdiri dari pembiayaan mudharabah dan pembiayaan musyarakah terhadap variabel terikat yaitu Return On Asset (ROA) Bank Pembiayaan Rakyat Syariah di Indonesia. Model persamaan yang digunakan adalah:

$Y=\alpha_{0}+\beta_{1 \ln } X_{1}+\beta_{2} \ln X_{2}+\mu$

Keterangan:

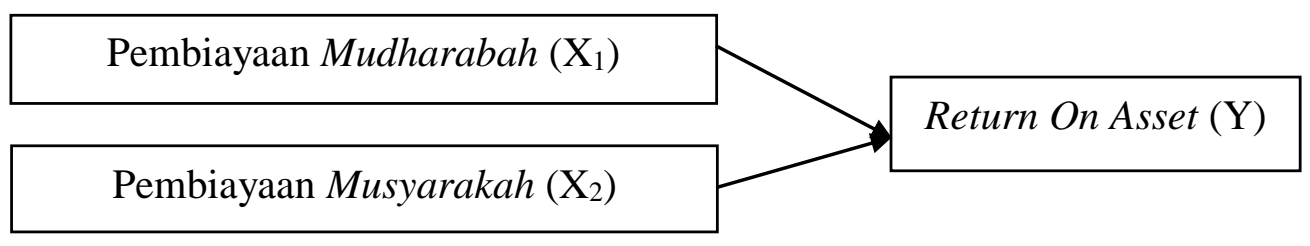

Keterangan :

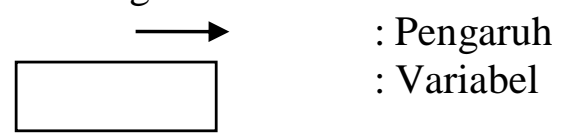

$$
\begin{array}{ll}
\mathrm{Y} & =\text { Return On Asset }(\text { ROA }) \\
\mathrm{X}_{1} & =\text { pembiayaan mudharabah } \\
\mathrm{X}_{2} & =\text { pembiayaan musyarakah }
\end{array}
$$




$$
\begin{array}{ll}
\alpha_{0} & =\text { Intercept } \\
\ln & =\text { Logaritma natural } \\
\beta_{1}, \beta_{2}, & =\text { Regresi dengan koefisien dari setiap variabel } \\
\mu & =\text { Pengganggu variabel }
\end{array}
$$

\section{HASIL ANALISIS DAN PEMBAHASAN}

\section{Uji Normalitas}

Tabel 1. Jarque-Berra Uji (JB Test)

\begin{tabular}{l|l}
\hline \multicolumn{2}{c}{ Uji Jarque-Bera: } \\
\hline Jarque-Bera & 1288.212 \\
\hline Kemungkinan & 0.000000 \\
\hline Sumber: (Eviews 9.0, 2019)
\end{tabular}

Sumber: (Eviews 9.0, 2019)

Nilai probabilitas JB Test adalah 0.000000. Nilai tersebut lebih kecil dari $\alpha=0,05$. Hal itu berarti error term tidak terdistribusi normal pada model regresi linier berganda tersebut.

\section{Uji Autokorelasi}

Tabel 2. Breusch-Godfrey Serial Correlation Uji LM

\begin{tabular}{l|l|l|l}
\hline \multicolumn{4}{c}{ Breusch-Godfrey Serial Correlation LM Test: } \\
\hline F-statistik & 0.611950 & Prob. F $(2,13)$ & 0.5487 \\
\hline Obs * R-squared & 1.367321 & Prob. Chi-Square (2) & 0.5048 \\
\hline
\end{tabular}

Sumber: Eviews 9.0, 2019

Berdasarkan hasil uji tersebut, nilai probabilitas Obs $* \mathrm{R}$-squared adalah 0.5048. Nilai itu lebih besar dari $\alpha=0,05$. Hal itu berarti tidak terdapat autokorelasi pada model regresi linier berganda tersebut. Hal tersebut juga bermakna yaitu tidak ada korelasi di antara anggota serangkaian observasi yang diurutkan menurut waktu atau ruang.

\section{Uji Heteroskedastisitas}

Tabel 3. Uji Heteroskedastisitas

\begin{tabular}{l|l|l|l}
\hline \multicolumn{4}{c}{ Heteroskedasticity Test: Breusch-Pagan Godfrey } \\
\hline F-statistik & 1.199200 & Prob. F (3,15) & 0.3142 \\
\hline Obs *R-squared & 2.439162 & Prob. Chi-Square (2) & 0.2954 \\
\hline
\end{tabular}

Sumber: (Eviews 9.0, 2019) 
Berdasarkan hasil uji tersebut, nilai probabilitas Obs * R-Square adalah 0.2954. Ini adalah nilai yang lebih besar dari $\alpha=0,05$. Ini berarti tidak ada heteroskedastisitas dalam model regresi linier berganda tersebut. Hal tersebut juga bermakna yaitu suatu model regresi linier tersebut memiliki varians residual yang konstan.

\section{Uji Multikolinieritas}

Tabel 4. Matriks Korelasi

\begin{tabular}{c|c|c}
\hline & Mudharabah (X1) & Musyarakah (X2) \\
\hline Mudharabah (X1) & 1.000000 & 0.162619 \\
\hline Musyarakah (X2) & 0.162619 & 1.000000 \\
\hline
\end{tabular}

Sumber: (Eviews 9.0, 2019)

Berdasarkan hasil uji multikolinieritas melalui matriks korelasi tersebut, hubungan antar variabel bebas antara pembiayaan mudharabah dengan pembiayaan musyarakah ialah tidak mengalami multikolinearitas karena nilai matriks korelasi pembiayaan mudharabah dengan pembiayaan musyarakah itu kurang dari 0,8.

Menurut (Arifieanto, 2012), sedikit multikolinieritas tidak sampai mengubah sifat parameter OLS sebagai Best Linear Unbiased Estimator (BLUE). Parameter yang diperoleh adalah tetap valid untuk mencerminkan kondisi populasi. Hal ini berarti ketika tidak ada multikolinieritas berarti parameter yang digunakan ialah valid.

\section{Hasil Regresi Linier Berganda}

Tabel 5. Hasil Regresi Linier Berganda

\begin{tabular}{l|l|c|c}
\hline \multicolumn{1}{c|}{ Variabel } & \multicolumn{1}{|c|}{ Koefisien } & t-Stat & Probabilitas (t-stat) \\
\hline X1 (Mudharabah) & 0.431293 & 0.786531 & 0.4372 \\
\hline X2 (Musyarakah) & -1.172083 & -1.255587 & 0.2181 \\
\hline C & 21.03373 & 0.775715 & 0.4434 \\
\hline R-squared & 0.055114 & \\
\hline F-Stat & 0.962420 & \\
\hline Probabilitas (F-stat) & 0.392430 &
\end{tabular}

Sumber: (Eviews 9.0, 2019)

Berdasarkan tabel 5 Nilai koefisien determinasi (R-Squared) yaitu 0.055114. Nilai R-Squared tidak baik karena lebih kecil dari 1. Ini berarti 5,51 persen variabel ROA dapat dijelaskan oleh pembiayaan mudharabah dan musyarakah, sedangkan sisanya 94,49 persen dijelaskan oleh variabel lain yang tidak diteliti. Selanjutnya Uji simultan (uji F) dilakukan untuk mengetahui pengaruh variabel-variabel bebas secara simultan terhadap variabel terikat. Lalu, uji parsial (uji $\mathrm{T}$ ) dilakukan untuk mengetahui pengaruh masingmasing variabel bebas terhadap variabel terikat. Adapun persamaan model pada penelitian ini yaitu: 
$\mathrm{ROA}=21,03373+0,431293 \ln \mathrm{X}_{1}-1,172083 \ln \mathrm{X}_{2}$

Berdasarkan rumus 1 terdapat nilai 21,03373. Hal itu berarti variabel ROA bertambah 21,03373 satuan ketika tidak terjadi penyaluran dana dalam bentuk pembiayaan mudharabah dan pembiayaan musyarakah. Selanjutnya berdasarkan pada tabel 5 secara simultan variabel mudharabah dan musyarakah tidak berpengaruh secara signifikan terhadap ROA dengan arah positif dengan nilai F-Statistik sebesar 0.962420 dan probabilitasnya sebesar 0.392430 atau $0,39 \%$ lebih dari confidence level sebesar $0,05(5 \%)$ artinya ketika pembiayaan mudharabah dan musyarakah mengalami kenaikan atau penurunan akan berdampak pada ROA namun dampaknya tidak signifikan. Hal ini sejalan dengan penelitian dari (Fatmawati, 2016) menunjukan bahwa secara simultan pembiayaan mudharabah, musyarakah, dan murabahah tidak berpengaruh ke arah positif secara signifikan terhadap ROA BPRS Artha Surya Barokah Semarang.

Hal ini tidak berpengaruhnya pembiayaan mudharabah dan pembiayaan musyarakah secara bersama-sama terhadap ROA BPRS di Indonesia. Secara hakikat pembiayaan mudharabah dan musyarakah memiliki tujuan yang positif karena secara tidak langsung bank syariah memberikan edukasi kepada masyarakat untuk berbisnis karena konsep bagi hasil dirasa tidak memberatkan nasabah dan juga dapat meningkatkan pertumbuhan ekonomi Indonesia. Namun bagi pihak bank syariah kedua pembiayaan tersebut memiliki risiko yang tinggi karena terdapat ketidak pastian tergantung pada realisasi bisnis dari nasabah. Sehingga jika bisnis tersebut sedang mengalami penurunan maka jumlah bagi hasil yang didapatkan pihak bank syariah akan menurun begitu pun sebaliknya ketika bisnis sedang mengalami kenaikan maka jumlah bagi hasil yang didapatkan pihak bank syariah akan meningkat pula. Hal ini yang membuat pihak bank syariah merasa terbebani maka dari itu saat ini bank syariah lebih mengedepankan produk murabahah dibandingkan dengan produk pembiayaan murdharabah dan pembiayaan musyarakah, dapat dilihat di gambar 2 dibawah ini:

Gambar 2. Statistik Akad Pembiayaan BPRS di Indonesia

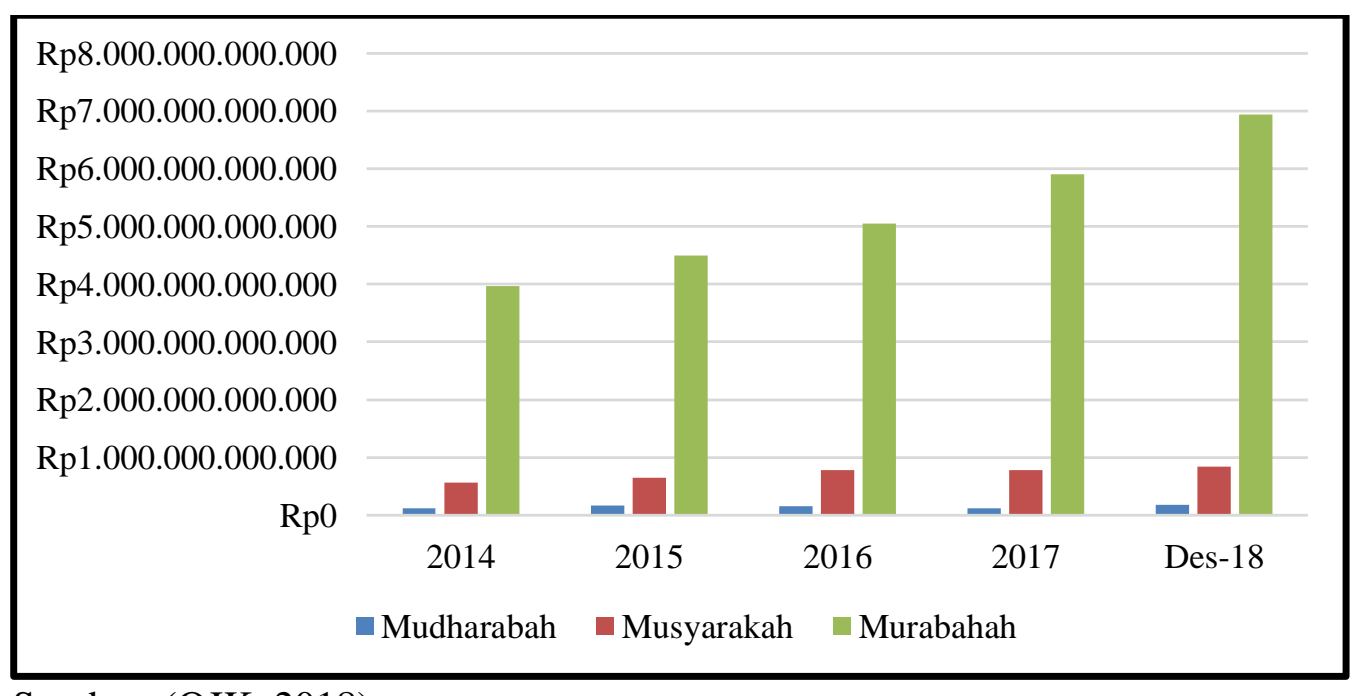

Sumber: (OJK, 2018) 
Berdasarkan gambar 2 diatas dari tahun 2014 hingga Desember 2018 pembiayaan murabahah mencapai Rp6,940,379,000,000 sedangkan pembiayaan mudharabah sebesar Rp180,956,000,000 dan pembiayaan musyarakah sebesar Rp837,915,000,000. Artinya pembiayaan murabahah lebih tinggi dibandingkan dengan pembiayaan mudharabah dan pembiayaan musyarakah pada periode Desember 2018. Oleh karena itu pembiayaan mudharabah dan musyarakah tidak berpengaruh signifikan terhadap ROA.

Bank syariah memiliki kelemahan dalam peranan bagi hasil dalam memainkan operasional investasi dana bank disebabkan oleh beberapa alasan yaitu pertama, adanya anggapan bahwa standar moral yang berkembang mayoritas komunitas muslim memberikan kebebasan dalam penggunaan bagi hasil sebagai mekanisme investasi. Sehingga mendorong pihak bank untuk mengontrol atau memantau secara insentif setiap dana yang di investasikan kepada pengelola dana, hal ini memberikan kesan operasional bank berjalan tidak ekonomis dan tidak efisien. Kedua, keterkaitan bank dalam pembiayaan sistem bagi hasil untuk membantu masyarakat atau nasabah dalam pengembangan usaha yang lebih banyak melibatkan pengusaha secara langsung dari pada sistem lainnya, pihak bank pun memiliki pengaruh disetiap pengambilan keputusan dalam bisnisnya sehingga dari jika terdapat keterlibatan yang tinggi akan mengecilkan kebebasan pengusaha sebenarnya pihak pemberi dana memberi kebebasan yang lebih dari pada ikut campur dalam penggunaan dana yang dipinjamkan. Ketiga, pemberian pembiayaan berdasarkan bagi hasil diperlukan kewaspadaan yang lebih tinggi bagi pihak bank sehingga bank syariah diperlukan meningkatkan kualitas pegawainya. Keempat, pemberian pembiayaan mudharabah dan musyarakah (sistem bagi hasil) jika terjadi kerugian maka pihak bank akan ikut menanggung kerugian bisnis yang dijalankan oleh pengelola dana, bagi pihak bank ikut menanggung risiko akan mendorong investasi yang lebih berisiko.

Sehingga berdasarkan risiko yang ada pada pemberian pembiayaan di bank syariah maka harus ada identifikasi dan penilaian risiko pembiayaan yang harus mempertimbangkan dua aspek yaitu: (1) Default Risk (risiko kebangkrutan) yaitu risiko yang terjadi pada first way out yang dipengaruhi oleh industry risk yaitu risiko yang terjadi pada jenis usaha yang ditentukan oleh karakteristik masing-maisng jenis usaha, kondisi eksternal perusahaan, dan faktor negatif lainnya yang dapat mempengaruhi kondisi keuangan nasabah. (2) Recovery Risk (risiko jaminan) yaitu risiko yang terjadi pada second way out yang disebabkan oleh kesempurnaan pengkatan jaminan, nilai jual kembali jaminan, faktor negatif lainnya, dan kredibilitas penjamin (Karim, 2010).

Berdasarkan tabel 5 secara parsial (1) variabel pembiayaan mudharabah tidak berpengaruh secara signifiakan terhadap ROA ke arah positif dengan nilai probabilitasnya sebesar 0,4372 lebih besar dari confidence level 0,05 (5\%) artinya ketika pembiayaan mudharabah mengalami peningkatan atau penurunan akan berdampak pada ROA namun dampaknya tidak signifikan. Koefisien regresi pembiayaan mudharabah adalah 0,431293. Koefisien tersebut bernilai positif berarti pembiayaan mudharabah berpengaruh positif terhadap ROA BPRS di Indonesia. Perubahan pembiayaan mudharabah searah dengan ROA. Apabila variabel pembiayaan mudharabah mengalami kenaikan sebesar 100 persen, variabel ROA akan mengalami kenaikan sebesar 43,1293 persen dengan asumsi variabel yang lain adalah konstan.

Tidak berpengaruhnya pembiayaan mudharabah pada BPRS di Indonesia karena akan meningkatkan biaya yang akan dikeluarkan oleh pihak BPRS dan memiliki tingkat 
risiko yang tinggi sehingga ROA yang didapat tidak sesuai yang diharapkan oleh pihak BPRS. Hal ini sejalan dengan penelitian dari (Nawawi, 2018) menunjukan bahwa secara parsial pembiayaan mudharabah berpengaruh positif dan tidak signifikan terhadap profitabilitas (ROA) pada BPRS HIK Bekasi kantor cabang Karawang. Menurut (Dharma dan Pristianda, 2018) mudharabah tidak berpengaruh terhadap profitabilitas (ROA) BPRS di Indonesia pada tahun 2012 hingga 2016. Selanjutnya menurut (Fadhila, 2015) menemukan bahwa mudharabah tidak berpengaruh terhadap laba Bank Syariah Mandiri.

Pembiayaan mudharabah secara definisi merupakan suatu akad kerja sama usaha antara pemilik dana dan pengelola dana, keuntungan dibagi atas nisbah yang disepakati. Oleh karena itu, hasil pembiayaan mudharabah bersifat tidak pasti sesuai dengan pencapaian keuntungan usaha dari pengelola dana, maka perhitungan keuntungan yang didapatkan kedua belah pihak akan berubah-ubah sesuai dengan pencapaian keuntungan usaha sehingga menyebabkan pembiayaan mudharabah kurang diminati khususnya bagi pihak bank syariah sendiri karena memiliki risiko yang tinggi. Hasil usaha dan risiko dalam keuangan Islam dapat dikaitkan dengan firman Allah SWT surat Luqman ayat 34 sebagai berikut:

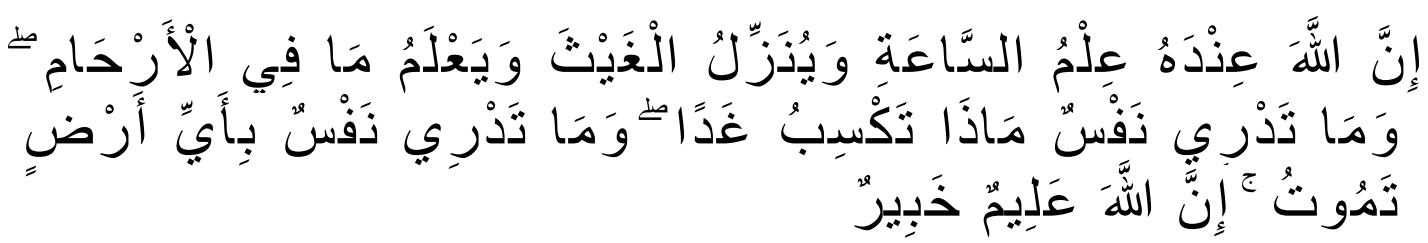

"Sesungguhnya Allah, hanya pada sisi-Nya sajalah pengetahuan tentang Hari Kiamat; dan Dia-lah Yang menurunkan hujan, dan mengetahui apa yang ada dalam rahim. Dan tiada seorang pun yang mengetahui (dengan pasti) apa yang akan diusahakannya besok. Dan tiada seorangpun yang dapat mengetahui di bumi mana dia akan mati. Sesungguhnya Allah Maha Mengetahui lagi Maha Mengenal."

Berdasarkan ayat diatas bahwa dalam kehidupan di dunia terdapat 5 kejadian yang hanya Allah yang mengetahui yaitu kapan hari kiamat, kapan hujan, apa yang ada dalam rahim, kepastian hasil usaha dimasa yang akan datang (esok), dan dimana manusia akan mati. Sehingga dari ke-5 ketidakpastian tersebut salah satu yang sering dihadapi dalam bisnis yaitu manusia tidak mengetahui kepastian hasil usaha dimasa yang akan datang (Nafik dan Wahyudi, 2018).

Selanjutnya (2) variabel pembiayaan musyarakah, tidak berpengaruh ke arah negatif secara signifiakan terhadap ROA dengan nilai probabilitasnya sebesar 0,2181 lebih besar dari confidence level $0,05(5 \%)$ artinya ketika pembiayaan musyarakah mengalami peningkatan atau penurunan akan berbanding terbalik dengan ROA. Koefisien regresi pembiayaan musyarakah adalah - 1,172083. Koefisien tersebut bernilai negatif berarti pembiayaan musyarakah berpengaruh negatif terhadap ROA BPRS di Indonesia. Perubahan pembiayaan musyarakah tidak searah dengan ROA. Apabila variabel pembiayaan musyarakah mengalami kenaikan sebesar 100 persen, variabel ROA akan mengalami penurunan sebesar 117,2083 persen dengan asumsi variabel yang lain adalah konstan 
Pembiayaan musyarakah secara parsial tidak berpengaruh signifikan terhadap ROA Bank Pembiayaan Rakyat Syariah di Indonesia. Hasil penelitian ini diperkuat dengan hasil penelitian yang dilakukan oleh (Jurino dan Renny, 2017) yang menyatakan bahwa hasil dari penelitiannya menunjukan bahwa pembiayaan musyarakah tidak mempengaruhi profitabilitas bank. Menurut (Fatmawati, 2016) pembiayaan musyarakah secara parsial tidak berpngaruh signifikan dan negatif terhadap ROA BPRS Artha Surya Barokah Semarang. Menurut (Ayunda, 2015) pembiayaan musyarakah dan NPF memiliki pengaruh negatif signifikan terhadap ROA BPRS di Indonesia periode Januari 2010 hingga Maret 2015. Menurut (Rokhmah dan Komariah, 2017) pembiayaan musyarakah tidak berpengaruh signifikan terhadap profitabilitas pada BUS di Indonesia. Menurut (Munawwara, 2016) menunjukan bahwa pembiayaan musyarakah berpengaruh secara negatif terhadao ROA di BMT Fastabiqul Khaerat Makassar.

Menurut (Sumiyato, 2008) pembiayaan merupakan aktivitas penyaluran dana yang terkumul kepada anggota pengguna dana, memilih jenis usaha yang akan didanai agar menemukan jenis usaha yang produktf, menguntungkan dan dikelola oleh anggota yang jujur dan bertanggung jawab. Pembiayaan musyarakah memiiliki arah hubungan yang negatif terhadap ROA hal ini terdapat faktor ketidakpastian pada hasil yang didapatkan dari pengelolaan dana yang diberikan kepada nasabah. Hal ini memiliki risiko yang cukup besar sehingga kesuksesan usaha dapat mempengaruhi keuntungan yang didapatkan pihak BPRS (Munawwara 2016).

\section{KESIMPULAN}

Berdasarkan hasil analisis dan pembahasan yang telah dijelaskan, ada beberapa kesimpulan sebagai berikut: (1) Pembiayaan mudharabah dan pembiayaan musyarakah secara simultan tidak berpengaruh signifikan arah negatif terhadap ROA Bank Pembiayaan Rakyat Syariah di Indonesia. (2) Pembiayaan mudharabah secara parsial tidak berpengaruh signifikan arah positif terhadap ROA Bank Pembiayaan Rakyat Syariah di Indonesia. Pembiayaan musyarakah secara parsial tidak berpengaruh signifikan arah negatif terhadap ROA Bank Pembiayaan Rakyat Syariah syariah di Indonesia.

Berdasarkan hasil penelitian ini maka terdapat beberapa saran sebagai berikut: (1) Bank Pembiayaan Rakyat Syariah sebaiknya meningkatkan pembiayaan mudharabah dan pembiayaan musyarakah karena masing-masing penyaluran dana tersebut berpengaruh pada sektor produktif dan posisi saat ini jumlah pembiayaan mudharabah dan jumlah pembiayaan musyarakah tidak dalam jumlah besar sehingga tidak berpengaruh positif signifikan terhadap ROA bank pembiayaan rakyat syariah di Indonesia. (2) Pembiayaan murabahah masih menjadi motor pembiayaan yang disalurkan oleh bank pembiayaan rakyat syariah di Indonesia. Bank pembiayaan rakyat syariah tetap menyalurkan pembiayaan murabahah dalam jumlah besar disertai dengan fokus pembiayaan konsumtif yang mengarah pada sektor produktif.

\section{DAFTAR PUSTAKA}

Agza, Yunita dan Darwanto. (2017). Pengaruh Pembiayaan Murabahah, Musyarakah dan Biaya Transaksi Terhadap Profitabilitas Bank Pembiayaan Rakyat Syariah. 
Iqtishadia Jurnal Kajian Ekonomi dan Bisnis Islam. Vol. 10 No. 1 hlm. 225-245

DOI: http://dx.doi.org/10.21043/iqtishadia.v10i1.2433.

Antonio, Muhammad Syafi'i. (2001). Bank Syariah: dari Teori ke Praktik. Jakarta: Gema Insani Press

Ariefianto, Mochammad Doddy. (2012). Ekonometrika: Esensi dan Aplikasi Menggunakan EViews. Jakarta: Erlangga.

Arifin, Agus Zainul. (2003). Dasar-Dasar Manajemen Bank Syariah. Jakarta: AlvaBet. Ascarya. (2011). Akad \& Produk Bank Syariah. Jakarta: PT. Raja Grafindo Persada.

Ayunda, Revalia. (2015). Pengaruh Penyaluran Pembiayaan Mudharabah, Pembiayaan Musyarakah, Pembiayaan Murabahah, dan Non performing Financing (NPF) terhadap Kinerja Bank Pembiayaan Rakyat Syariah di Indonesia Periode Januari 2010-Maret 2015. Skripsi Universitas Islam Negeri Syarih Hidayatullah Jakarta.

Dewi, Ratih Komala. (2019). Pengaruh Pembiayaan Mudharabah dan pembiayaan Musyarakah Terhadap Return On Asset (ROA) pada Bank Syariah Mandiri. Jurnal Baabu Al-Ilmi Ekonomi dan Perbankan Syariah Vol. 4 No. 2 hlm. 227-292.

Dharma, Yulius dan Pristianda, Ade. (2018) Pengaruh Pembiayaan Mmudharabah dan Murabahah terhadap Profitabilitas (Return on Assets) Bank Pembiayaan Rakyat Syariah di Indonesia 2012-2016. Jurnal Ekonomika Indonesia. Vol VII No. 2 hal. 60-64 P-ISSN: 2338-4123E-ISSN:2614-7270.

Fadhila, Novi. (2015). Analisis Pembiayaan Mudharabah dan Murabahah terhadap Laba Bank Syariah Mandiri. Jurnal Riset Akuntansi dan Bisnis. Vol 15 No. 1 hal. 65-77.

Fatmawati, Ratih. (2016). Analisis Pengaruh Pembiayaan Mudharabah, Musyarakah, dan Murabahah terhadap Kemampuan Laba BPR Syariah Artha Surya Barokah Semarang. Skripsi Universitas Muhammadiyah Semarang.

Irmawati, Elli. (2018). Analisis pengaruh Pembiayaan Mudharabah, Musyarakah, Murabahah, dan Multijasa Terhadap Profitabilitas PT BPRS Lantabur Tebuireng Periode 2010-2017. Skripsi Universitas Islam Negeri Maulana Malik Ibrahim Malang.

Jurino dan Renny Wulandari, (2017). The Effect of Mudharabah and Musyarakah on The Profitability of Islamic Banks. Parahyangan Internasional Thrid Accounting and Business Conference.

Karim, Adiwarman. A. (2010). Bank Islam: Analisis Fiqh dan Keuangan. Jakarta: PT. Raja Grafindo Persada.

Muhammad. (2005a). Manajemen Bank Syariah. Yogyakarta: UPP AMP YKPN.

Muhammad. (2005b). Manajemen Dana Bank Syariah. Yogyakarta: Ekonisia.

Muhammad. (2005c). Manajemen Pembiayaan Bank Syariah. Yogyakarta: UPP AMP YKPN.

Munawwara. (2016). Pengaruh Pembiayaan Musyarakah terhadap Return On Asset (ROA) pada BMT Fastabiqul Khaerat Makassar. Skripsi Universitas Islam Negeri Alauddin Makassar.

Nafik H.R, Muhamad dan Wahyudi, Rofiul. (2018). Manajemen Bank Islam: Pendekatan Syariah dan Praktek. Yogyakarta: UAD Press.

Nawawi, Ahmad; Nurdiansyah, Dian Hakip; dan Al Qodliyah, Diffah Sri Addafi. (2018). Pengaruh Pembiayaan Mudharabah dan Musyarakah Terhadap Profitabilitas (ROA) Pada BPRS HIK Bekasi Kantor Cabang Karawang. FALAH Jurnal Ekonomi Syariah. Vol. 3, No.2 hal 1-9. 
Ogilo, Fredrick. (2016) Effects of Financial Instruments on Performance of Islamic Banks in Kenya. The International Journal Of Business \& Management.

Otoritas Jasa Keuangan. (2019) Statistik Perbankan Syariah. https://www.ojk.go.id/.

Permata, Russely Inti Dwi; Yaningwati, Fransisca; Zahroh Z.A. (2014) Analisis Pengaruh Pembiayaan Mudharabah dan Musyarakah terhadap Tingkat Profitabilitas ?(Return on Equity): Studi pada Bank Umum Syariah yang Terdaftar di Bank Indonesia). Jurnal Administrasi Bisnis (JAB). Vol. 12 No. 1 hlm. 1-9.

Rahmani, Nur Ahmadi Bi. (2019). Pengaruh Return On Assets (ROA), Return On Equity (ROE), Net Profit Margin (NPM), Dan Gross Profit Margin (GPM) Terhadap Harga Saham Perbankan Syariah Periode Tahun 2014-2018. KITABAH Volume 3. No. 2 hlm. 110-121.

Rivai, Veithzal; Veithzal, Andria Permata; Idroes, Ferry N. (2007). Bank and Financial Institution Management. Jakarta: PT RajaGrafindo Persada.

Rivai, Veitzhal; Sudarto, Sarwono; Hulmansyah; Wihasto, Hanan; dan Veitzhal Arifiandy Permata. (2012) Islami Banking \& Ficance. Dari Teori ke Praktik Bank dan Keuangan Syariah sebagai Solusi dan Bukan Alternatif. Edisi Pertama. Noverber 2012. Yogyakarta: BPFE.

Rokhmah, Laila dan Komariah, Euis (2017) Pembiayaan Mudharabah dan Musyarakah terhadap Profitabilitas pada Bank Umum Syariah di Indonesia. Jurnal Ilmiah MbiA Vol.16 No.1 hal 11-20.

Rosiana, Rita; Syihabudin; Nurmeilani, Siti (2019) The Influence of Profit Sharing Financing, Murabaha Financing, Non-Performing Financing, Inflation, and Exchange Rates on Profitability of Sharia Commercial Banks in Indonesia. Journal Islamic Economics, Finance and Banking Syi'ar Iqtishadi. Vol. 3 No. 1 hlm. 22-48.

Rustam, Bambang Rianto. (2013) Manajemen Risiko: Perbankan Syariah di Indonesia. Jakarta: Salemba Empat.

Sudrajat, Anton. (2015). Determinan Total Aset Bank Pembiayaan Rakyat Syariah (BPRS) di Pulau Jawa Tahun 2014. Islamic Economics Journal Vol. 1 No. $1 \mathrm{hlm}$. 133-149 http://dx.doi.org/10.21111/iej.vlil.348.

Sudana, I Made. (2009). Manajemen keuangan Teori dan Praktik. Surabaya: Airlangga University Press.

Sa'diyah, Mahmudatus dan Arifin, Meuthiya Athifa (2013) Mudharabah dalam Fiqih dan Perbankan Syari'ah. Equilibrium Vol. 2 No. 2 hlm. 302-323.

Sa'diyah, Mahmudatus dan Aziroh, Nur. (2014). Musyarakah dalam Fiqih dan Perbankan Syariah. Equilibrium Vol. 2 No. 2 hlm. 310-327.

Syofyan, Sofriza. (2003). "Keputusan "Go Public" dan Hubungannya dengan Kinerja Bank-Bank Swasta di Indonesia", Jurnal Media Riset \& Manajemen. Vol. 3, No. 1, April.

Sumiyato, A. (2008). BMT Menuju Koperasi Modern. Yogyakarta: PT. ISES Consulting Indonesia.

Yuliana, Sa'adah; Suhel; Bashir; and Abdul (2017) Comparative Analysis of Profit Sharing Financing Between Islamic Banks (BUS) and Islamic Rural Bank (BPRS) in Indonesia. International Journal of Economics and Financial Issues. 7(2), 266270 . 